Article

\title{
Chemical and Antimicrobial Analyses of Sideritis romana L. subsp. purpurea (Tal. ex Benth.) Heywood, an Endemic of the Western Balkan
}

\author{
Vanja Tadić ${ }^{1, \dagger}$, Alessandra Oliva ${ }^{2, \dagger}$, Mijat Božović ${ }^{3,4, *}$ (D), Alessia Cipolla ${ }^{2}$, \\ Massimiliano De Angelis ${ }^{2}$, Vincenzo Vullo ${ }^{2}$, Stefania Garzoli ${ }^{5}$ and Rino Ragno ${ }^{4,5, *}$ \\ 1 Institute of Medicinal Plants Research Dr Josif Pančić, Tadeuša Košćuška 1, 11000 Belgrade, Serbia; \\ vtadic@mocbilja.rs \\ 2 Department of Public Health and Infectious Diseases, Sapienza University, P.le Aldo Moro 5, 00185 Rome, \\ Italy; alessandra.oliva@uniroma1.it (A.O.); alessia.cipolla@hotmail.it (A.C.); \\ massimiliano.deangelis@yahoo.com (M.D.A.); vincenzo.vullo@uniroma1.it (V.V.) \\ 3 Faculty of Natural Sciences and Mathematics, University of Montenegro, Džordža Vašingtona bb, \\ 81000 Podgorica, Montenegro \\ 4 Rome Center for Molecular Design, Sapienza University, P.le Aldo Moro 5, 00185 Rome, Italy \\ 5 Department of Drug Chemistry and Technology, Sapienza University, P.le Aldo Moro 5, 00185 Rome, Italy; \\ stefania.garzoli@uniroma1.it \\ * Correspondence: mijat.bozovic@uniroma1.it (M.B.); rino.ragno@uniroma1.it (R.R.); \\ Tel.: +382-20-243-816 (M.B.); +39-06-4991-3937 (R.R.); Fax: +382-20-244-608 (M.B.); +39-06-4991-3627 (R.R.) \\ + These authors contributed equally to this work.
}

Received: 29 July 2017; Accepted: 18 August 2017; Published: 23 August 2017

\begin{abstract}
A comprehensive study on essential oil and different solvent extracts of Sideritis romana L. subsp. purpurea (Tal. ex Benth.) Heywood (Lamiaceae) from Montenegro is reported. The gas chromatography-mass spectrometry analysis of the essential oil revealed a total of 43 components with bicyclogermacrene $(23.8 \%)$, germacrene $\mathrm{D}(8 \%),(E)$-caryophyllene $(7.9 \%)$ and spathulenol $(5.5 \%)$ as the major ones. Sesquiterpenoid group was found to be the most dominant one $(64.8 \%)$, with $19.9 \%$ of the oxygenated forms. In the crude methanol extract of the investigated plant, obtained by Sohhlet exraction, the total phenol content was $14.7 \pm 0.4 \mathrm{mg}$ of GA/g, the total flavonoids were $0.29 \pm 0.03 \%$ expressed as hyperoside percentage, whereas the total tannins content was $0.22 \pm 0.04 \%$ expressed as pyrogallol percentage. For the antimicrobial activity determination, the following microorganisms have been used: methicillin-susceptible Staphylococcus aureus (MSSA (American Type Culture Collection (ATCC) 29213)) and methicillin-resistant S. aureus (MRSA (clinical strain)), Escherichia coli (ATCC 25922), carbapenem-susceptible Klebsiella pneumoniae (clinical strain), carbapenem-resistant K. pneumoniae (clinical strain) and Candida albicans (ATCC 14053). The essential oil showed high potency against MSSA and MRSA, both at high $\left(\sim 5 \times 10^{5} \mathrm{CFU} / \mathrm{mL}\right)$ and low $\left(\sim 5 \times 10^{3} \mathrm{CFU} / \mathrm{mL}\right)$ inoculum. With respect to MSSA, the minimal inhibitory concentration (MIC) value was $0.307 \mathrm{mg} / \mathrm{mL}$, with bactericidal activity obtained at $0.615 \mathrm{mg} / \mathrm{mL}$, while, in the case of MRSA, the MIC and minimal bactericidal concentration (MBC) values were 0.076 and $0.153 \mathrm{mg} / \mathrm{mL}$, respectively. Regarding anti-Candida albicans activity, the MIC value was $2.46 \mathrm{mg} / \mathrm{mL}$ without reaching fungicidal activity. In addition to the observed essential oil efficacy, different solvent extracts were analyzed for their antimicrobial activity. Similarly to the essential oil, thehighest efficacy was observed against both MSSA and MRSA strains, at high and low inoculums, in the case of the 1,2-dichloroethane and methanol extracts. A potent fungicidal activity has been also found for the $n$-hexane and 1,2-dichloroethane extracts. It can be concluded that Sideritis romana L. subsp. purpurea (Tal. ex Benth.) Heywood provides a wide range of application in different fields such as phytochemistry, pharmacology, toxicology or pharmacognosy.
\end{abstract}


Keywords: Sideritis romana L. subsp. purpurea (Tal. ex Benth.) Heywood; essential oil; solvent extracts; GC-MS; flavonoids; phenols; tannins; antimicrobial activity

\section{Introduction}

Essential oils (EOs) have been known since antiquity to possess different biological activities, notably antibacterial and antifungal, or antioxidant properties [1,2]. Generally, these activities depend on the chemical composition of EO that is determined by the plant genotype, but also greatly influenced by several factors such as geographical origin and environmental and agronomic conditions [3-5]. Many EOs and their ingredients have an unexpectedly large range of applications. Their cosmetic use is probably the most ancient one, both for their functional, perfume and preservative properties [6]. They have been widely used as food flavors [7], and possessing antioxidant and antimicrobial activities serve as natural additives in foods and food products [8]. Known for their antiseptic (i.e., bactericidal, virucidal and fungicidal), medicinal properties and their fragrance, EOs are used in embalmment, preservation of foods and as antimicrobial, analgesic, sedative, anti-inflammatory, spasmolytic and local anesthetic remedies [9].

Sideritis romana L. subsp. purpurea (Tal. ex Benth.) Heywood (SP) is an endemic of the Western Balkan. Although numerous scientific studies related to different Sideritis species confirmed biological effects of their active compounds [10-20], such studies considering this species are rather rare. To the best of our knowledge, there is only one report for SP collected in Greece [21]. Herein, we report for the first time a comprehensive study on its chemical composition and the related antimicrobial activity from material collected in Montenegro.

\section{Taxonomic Characterization and Uses of SP}

Purple ironwort [synonyms: S. purpurea Tal. ex Benth., Hesiodia purpurea (Tal. ex Benth.) Sojàk] from Lamiaceae family is a densely villous-lanate annual that grows up to $30 \mathrm{~cm}$. Its stem is eglandular, and leaves are 10-25 × 5-12 mm, oblong-ovate, dentate or crenate-dentate. Verticillasters are usually 6-flowered and distant. Calyx is 6-10 mm, 2-lipped; upper tooth is broadly ovate, lower lanceolate, all with a straight, pungent apex. Purple (or rarely white) corolla is 7-10 mm, equaling or slightly exceeding calyx, with the upper lip of 4-5 × 1-2 mm (Figure 1) [22].

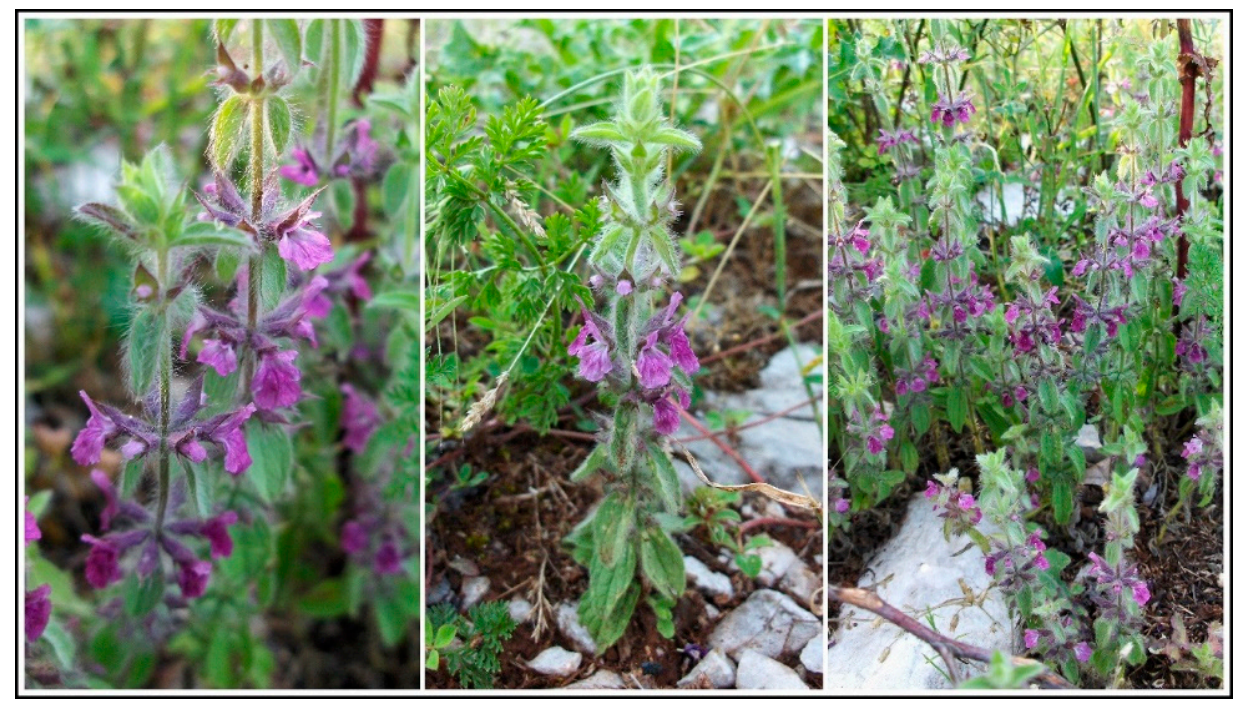

Figure 1. Sideritis romana L. subsp. purpurea (Tal. ex Benth.) Heywood in full blossom on its natural habitat in Šteke locality near Podgorica city (Montenegro) (photo by Mijat Božović). 
It inhabits dry, rocky places or abandoned meadows and arid grasslands, but can also be found on the edges of irrigation ditches or alleys, usually at lower altitudes. To the best of our knowledge, there is no particular report on any traditional use of this subspecies. However, different biological activities of other Sideritis species have been investigated by numerous authors [10-20]. A review work [23] on genus Sideritis has reported that these plants have been traditionally used for tea preparation, as flavoring agents, and in folk medicine in the Mediterranean and Balkan regions as anti-inflammatory, antiulcerative, antimicrobial, anticonvulsant, antispasmodic, antioxidant, vulnerary, analgesic and carminative agents. According to the authors, diterpenes, flavonoids and EOs occurring in almost each species are the compounds mainly responsible for the observed in vivo and in vitro pharmacological activities. Sideritis is used in Turkish folk medicine as beverage in brew form for its high antibacterial, carminative, diuretic and digestive properties [24]. The species from this genus are used for its vulnerary properties to heal cuts and wounds of the skin [25], while, in some Italian regions, the decoy of the exsiccated leaves is used to wash the unconcealed parts of the body in case of fright in order to soothe anxiety [26].

\section{Results and Discussion}

\subsection{EO and Solvent Extractions}

SP essential oil (SPEO) isolated by hydrodistillation from the crushed dried plant material was obtained as a yellow liquid with a yield of $0.015 \% w / w$ (calculated per weight of dried material).

Solvent extracts yields are shown in Tables 1 and 2. In general, the methanol extracts furnished the highest yields.

Table 1. Maceration extraction: final extracts yield (in grams).

\begin{tabular}{ccc}
\hline Sample Name & Solvent & Yield (Grams) \\
\hline A & methanol & 0.76 \\
B & $n$-hexane & 0.03 \\
C & 1,2-dichloroethane & 0.03 \\
D & ethyl-acetate & 0.05 \\
E & chloroform & 0.02 \\
\hline
\end{tabular}

Table 2. Soxhlet extraction: final extracts yield \%.

\begin{tabular}{ccc}
\hline Sample Name & Solvent & Yield \% $^{\mathbf{1}}$ \\
\hline $\mathrm{F}$ & methanol & 0.254 \\
$\mathrm{G}$ & acetone & 0.176 \\
$\mathrm{H}$ & diethyl-ether & 0.191 \\
\hline \multicolumn{3}{c}{${ }^{1}$ calculated per plant material weight. }
\end{tabular}

\subsection{EO Chemical Analysis}

Detected components and their percentages according to their relative retention indices (RI) are given in Table 3. A total of 43 components was determined, representing $90.4 \%$ of the EO. The major components were bicyclogermacrene $(23.8 \%)$, germacrene $\mathrm{D}(8 \%),(\mathrm{E}$ or $\beta$, but one throughout the text)-caryophyllene (7.9\%) and spathulenol (5.5\%). Sesquiterpenoid group was found to be the most dominant one $(64.8 \%)$, with $19.9 \%$ of the oxygenated forms. Mono- and diterpene fractions were present only with oxygenated forms: $4.4 \%$ and $5.7 \%$, respectively.

Many studies have been performed on the chemical composition of EOs from different Sideritis species, explaining the polymorphism among the populations, as well as the existence of new species, chemical varieties and hybrids. Numerous studies have reported the influence of the geographical location, season, climatological variations, plant variety and experimental conditions on EO composition of Sideritis species, and a possible existence of chemotypes or ecotypes has also been noted [27-30]. 
The most common terpene group of constituents among Sideritis species is almost absent, since some species are rich in monoterpenoids, while others are characterized by the prevalence of sesquiterpenoid fraction, or even diterpenes [21,31]. According to the most prevalent compounds, some authors classified Sideritis species into six main groups: monoterpene hydrocarbon-rich, oxygenated monoterpene-rich, sesquiterpene hydrocarbon-rich, oxygenated sesquiterpene-rich, diterpene-rich and others [31].

High content of monoterpene hydrocarbons has been reported in many studies, with $\alpha$-pinene, $\beta$-pinene, sabinene, myrcene or limonene as the main ones [27,30-33]. Thus, some Greek endemic S. clandestina subspecies are rich in $\alpha$ - and $\beta$-pinene [21], as well as S. congesta and S. argyrea EOs [34]. The Spanish endemic $S$. ibanyezii has been found to be rich in sabinene and $\alpha$-pinene [32,35], and the same monoterpenes along with fenchone and cineole were in prevalence in S. pusilla from the Iberian Peninsula [36]. Limonene was found as the major compound in S. perfoliata [34], and the prevalence of myrcene has been reported for S. syriaca [37].

Table 3. Chemical composition of SPEO. Values are in weight $\%$.

\begin{tabular}{|c|c|c|c|c|c|c|c|}
\hline$\#^{1}$ & Compound Name & $\mathrm{KI}^{2}$ & $\%$ & $\#^{1}$ & Compound Name & $\mathrm{KI}^{2}$ & $\%$ \\
\hline 1 & 1,8-cineole & 1026 & 0.3 & 23 & viridiflorol & 1592 & 0.8 \\
\hline 2 & camphor & 1141 & 0.3 & 24 & 8-cedren-13-ol & 1688 & 1.1 \\
\hline 3 & trans-chrysanthenyl acetate & 1235 & 0.2 & 25 & myristic acid & 1770 & 1.1 \\
\hline 4 & $\alpha$-terpinyl acetate & 1346 & 3.1 & 26 & isopropyl tetradecanoate & 1828 & 1.7 \\
\hline 5 & $\gamma$-ylangene & 1374 & 0.2 & 27 & hexahydrofarnesyl acetone & 1848 & 6.9 \\
\hline 6 & $\alpha$-copaene & 1377 & 1 & 28 & $(5 E, 9 E)$-farnesyl acetone & 1913 & 0.5 \\
\hline 7 & $\beta$-bourbonene & 1387 & 0.4 & 29 & phytol & 1942 & 0.9 \\
\hline 8 & $\beta$-(E)-demascenone & 1383 & 0.5 & 30 & palmitoleic acid & 1953 & 0.5 \\
\hline 9 & $\beta$-elemene & 1384 & 0.6 & 31 & palmitic acid & 1959 & 7.6 \\
\hline 10 & $(E$ or $\beta)$-caryophyllene & 1417 & 7.9 & 32 & isopropyl hexadecanoate & 2024 & 0.6 \\
\hline 11 & endo-arbazol & 1433 & 0.2 & 33 & manool & 2056 & 0.9 \\
\hline 12 & aromadendrene & 1439 & 0.3 & 34 & epi-manool & 2059 & 0.3 \\
\hline 13 & $\alpha$-humulene & 1452 & 0.4 & 35 & octadecanol & 2077 & 0.6 \\
\hline 14 & $\beta$-farnesene & 1454 & 0.4 & 36 & phytol acetate & 2218 & 1.9 \\
\hline 15 & $\gamma$-muurolene & 1478 & 0.9 & 37 & $3 \alpha$-hydroxy manool & 2297 & 0.9 \\
\hline 16 & germacrene D & 1484 & 8 & 38 & 3-deoxy estradiol & 2300 & 0.8 \\
\hline 17 & bicyclogermacrene & 1500 & 23.8 & 39 & torulosol & 2360 & 0.8 \\
\hline 18 & 10-epi-italicene ether & 1515 & 1.6 & 40 & pentacosane & 2500 & 0.7 \\
\hline 19 & $\delta$-cadinene & 1522 & 1 & 41 & hexacosane & 2600 & 0.5 \\
\hline 20 & spathulenol & 1577 & 5.5 & 42 & heptacosane & 2700 & 0.1 \\
\hline 21 & caryophyllene oxide & 1582 & 2 & 43 & nonacosane & 2900 & 1.1 \\
\hline 22 & globulol & 1590 & 1.5 & & Unidentified compounds & & 9.6 \\
\hline
\end{tabular}

${ }^{1}$ \# indicates the compound identification number; ${ }^{2}$ Kovats index, experimentally determined.

Oxygenated derivatives are not common as main constituents among Sideritis species. Oxygenated forms of monoterpenes are characteristic constituents only in several species: S. arguta, S. libanotica and S. romana [31,38]. Oxygenated sesquiterpenes predominate in EOs of S. phlomoides and S. taurica [31], while in the group rich in sesquiterpenes, $\beta$-caryophyllene, germacrene D and calamene have been identified as the main constituents [19]. Thus, the Greek endemic S. euboea was dominated by the presence of sesquiterpenes, with the oxygenated sesquiterpene valeranone being the main component, followed by $\beta$-caryophyllene and $\gamma$-muurolene [21]. Sesquiterpenoids $\beta$-caryophyllene and nerolidol dominated in S. scardica [37], while germacrene D and bicyclogermacrene were found in prevalence in S. montana, S. curvidens and S. raeseri $[31,37,39]$. S. lanata was also characterized by the abundance of sesquiterpenes, with spathulenol and $\beta$-phellandrene being the major metabolites [21,31], while S. condensata provided an EO with high proportions of $\beta$-caryophyllene and $\alpha$-pinene [34]. S. perfoliata and S. dichotoma are rich in diterpenes [40], as well as an Greek endemic S. clandestina subsp. peloponnesiaca with the labdane derivative isoabienol being the major diterpene constituent [21]. S. lanata formed a distinct group with the occurrence of a fatty acid as main constituent in the EO [31].

To the best of our knowledge, there is only one report for SPEO from plant collected inGreece [21]. That analysis also showed predominance of sesquiterpene fraction (83.6\%) with bicyclogermacrene $(48.9 \%), \beta$-caryophyllene $(12.7 \%)$ and $\gamma$-muurolene $(11.9 \%)$ as the major ones. Monoterpenes were 
present in $16.2 \%$ with $\beta$-pinene $(7.9 \%)$ being the main metabolite. The results presented herein are partly in compliance with the ones previously reported. It is also worth noting that the other subspecies romana was found to be rich in oxygenated monoterpenes with thymol (24.9\%) being the most abundant in the material from Turkey [31] and carvacrol (20\%) in the Italian-origin material [38]. Montenegrin SP can thus be described as the sesquiterpenoids-rich one, with $10.1 \%$ of the oxygenated mono- and diterpene fractions being less important.

\subsection{Total Phenolic, Flavonoid and Tannin Contents}

Medicinal plants are known to produce diverse substances possessing antioxidant properties that have the ability to protect the human body against cellular oxidation [41]. Antioxidant compounds as different classes of secondary metabolites like polyphenolic acids, different groups of flavonoids, including flavonols, flavons, flavanones, flavanonols, isoflavonoids, antocyanidis, derivatives of flavan 3-ols (tannins), flavan-3,4-diols, are well known to be able to scavenge free radicals and thus inhibit the oxidative mechanisms that lead to degenerative diseases [42].

Phenolic compounds are a class of antioxidants that act as free radical terminators and their bioactivities may be related to their abilities to chelate metals, inhibit lipoxygenase and scavenge free radicals [43]. The phenol content of a plant depends on a number of intrinsic (genetic, extracting solvent) and extrinsic (environmental, handling and development stage) factors [44]. Total phenolic content (TPC) in the methanol SP extract (F) using the Folin-Ciocalteu's reagent was expressed in terms of gallic acid equivalent (mg of GA/g of extract) and it was $14.7 \pm 0.4$. Similar results were obtained with S. lycia and S. libanotica being 16.05-18.04 and 9.16-10.49 mg GA/g, respectively [45], while higher TPC has been reported for S. raeseri (15.3 to $34.1 \mathrm{mg} \mathrm{GA} / \mathrm{g})$, S. scardica (188.5 $\pm 12.9 \mathrm{mg} \mathrm{GA} / \mathrm{g}$ ), S. amasiaca, S. serratifolia (from $402.5 \pm 2.5$ to $321.1 \pm 0.5 \mathrm{mg} \mathrm{GA} / \mathrm{g}$ ), S. condensata and S. eryhrantha samples (from $247.62 \pm 1.91$ to $217.61 \pm 0.95 \mathrm{mg} \mathrm{GA} / \mathrm{g}$ ) [20,39,46-48]. It is well-known that phenolic compounds contribute to quality and nutritional value in terms of modifying color, taste, aroma, and flavor and also in providing health beneficial effects. They also serve in plant defense mechanisms to counteract reactive oxygen species in order to survive and prevent molecular damage and damage by microorganisms, insects, and herbivores [49-51].

Although a group of compounds of relatively homogenous structure, the flavonoids exhibit wide range of activities, antimicrobial being one among others. Flavonoids were found to reduce blood-lipid and glucose and to enhance human immunity, as well. These compounds among others that contain hydroxyls are responsible for the radical scavenging effect [39,52]. The content of flavonoids (TFC) in the menthanol SP extract (F) was expressed as hyperoside percentage, and the TFC value was calculated as $0.29 \pm 0.03 \%$. Comparing with available literature data, this content is similar to that reported for S. raeseri and S. scardica [20,46]. It has been reported that light intensity, temperature and altitude could influence the biosynthesis of flavonoids [53].

Tannins are generally defined as naturally occurring polyphenolic compounds of high molecular weight. They have been accorded an important role in protecting plant tissues from herbivore attack [54]. Dietary supplementation of these compounds reduces the oxidative damage to cell membrane lipid, protein and nucleic acid due strong quenching property of free radicals [55]. Thus, these compounds also provide protection from cardiovascular, immune/autoimmune diseases and brain dysfunctions viz. Parkinson's, Alzheimer's, Huntington's diseases [56]. The content of tannins, expressed as pyrogallol percentage, in the methanol SP extract (F) was presented as the mean value of three determinations, resulting as $0.22 \pm 0.04 \%$, which is quite lower than in the case of S. scardica [20].

\subsection{Antimicrobial Activity}

The SPEO antimicrobial potency, compared with that of each reference compound, is shown in Table 4. The EO showed high activity against methicillin-susceptible Staphylococcus aureus (MSSA) and methicillin-resistant S. aureus (MRSA), both at high $\left(\sim 5 \times 10^{5} \mathrm{CFU} / \mathrm{mL}\right)$ and low $\left(\sim 5 \times 10^{3} \mathrm{CFU} / \mathrm{mL}\right)$ inoculum. In fact, with respect to MSSA, the minimal inhibitory concentration (MIC) value was 
$0.307 \mathrm{mg} / \mathrm{mL}$, with bactericidal activity obtained at $0.615 \mathrm{mg} / \mathrm{mL}$; in the case of MRSA, even stronger activity was observed, with the MIC and minimal bactericidal concentration (MBC) values of 0.076 and $0.153 \mathrm{mg} / \mathrm{mL}$, respectively.

Table 4. Activity of SPEO against different bacterial and fungal strains detected through microbroth dilution.

\begin{tabular}{|c|c|c|c|c|c|c|}
\hline Microorganism & $\begin{array}{l}\text { MIC Low } \\
\text { Inoculum } \\
(\mathrm{mg} / \mathrm{mL})\end{array}$ & $\begin{array}{c}\text { MBC Low } \\
\text { Inoculum } \\
(\mathrm{mg} / \mathrm{mL})\end{array}$ & $\begin{array}{l}\text { MIC High } \\
\text { Inoculum } \$ \\
(\mathrm{mg} / \mathrm{mL})\end{array}$ & $\begin{array}{l}\text { MBC High } \\
\text { Inoculum } \$ \\
(\mathrm{mg} / \mathrm{mL})\end{array}$ & Activity & $\begin{array}{c}\text { MIC Reference } \\
\text { Antimicrobial (mg/L) }\end{array}$ \\
\hline $\begin{array}{c}\text { MSSA } \\
\text { (ATCC 29213) }\end{array}$ & 0.307 & 0.615 & 0.307 & 0.615 & Bactericidal & 0.5 (VAN)-0.03 (RIF) \\
\hline MRSA * & 0.076 & 0.153 & 0.076 & 0.153 & Bactericidal & 1 (VAN)-0.06 (RIF) \\
\hline $\begin{array}{c}\text { E. coli } \\
\text { (ATCC 25922) }\end{array}$ & $>2.46$ & $>2.46$ & - & - & No effect & 0.125 (MEM) \\
\hline $\begin{array}{c}\text { CS } \\
\text { K. pneumoniae * }\end{array}$ & $>2.46$ & $>2.46$ & - & - & No effect & 0.25 (MEM) \\
\hline $\begin{array}{c}\mathrm{CR} \\
\text { K. pneumoniae * }\end{array}$ & $>2.46$ & $>2.46$ & - & - & No effect & 16 (MEM) \\
\hline $\begin{array}{c}\text { C. albicans } \\
\text { (ATCC 14053) }\end{array}$ & 2.46 & $>2.46$ & - & - & Fungistatic & 0.25 (FLU) \\
\hline
\end{tabular}

${ }^{\circ}$ Low inoculum: $5 \times 10^{3} \mathrm{CFU} / \mathrm{mL}$; ${ }^{\S}$ High inoculum: $5 \times 10^{5} \mathrm{CFU} / \mathrm{mL} ;{ }^{*}$ clinical strain; MSSA: methicillinsusceptible S. aureus; MRSA: methicillin-resistant S. aureus; CS: carbapenem-susceptible; CR: carpabenem-resistant; ATCC: American Type Culture Collection; MIC: Minimal Inhibitory Concentration Value; MBC: Minimal Bactericidal Concentration Value; CS: carbapenem-susceptible; CR: carbapenem-resistant; VAN: vancomycin; RIF: rifampin; MEM: meropenem; FLU: fluconazole.

In contrast, no effect was found for E. coli, carbapenem-susceptible and carbapenem-resistant K. pneumoniae, with the MIC values for both pathogens $>2.46 \mathrm{mg} / \mathrm{mL}$. Regarding the antifungal activity of SPEO, the MIC value was $2.46 \mathrm{mg} / \mathrm{mL}$ for C. albicans, without reaching fungicidal activity $(\mathrm{MBC}>2.46 \mathrm{mg} / \mathrm{mL})$.

In addition to observed activity of SPEO against Gram(+) microorganisms and C. albicans, SP extracts have been investigated as well. With the aim to assess the antimicrobial efficacy, the extracts were analysed against MSSA, MRSA and C. albicans. The results are shown in Table 5. Similarly to the activity of SPEO, the highest efficacy was observed against both MSSA and MRSA strains, at high and low inoculum, for the extracts $\mathbf{C}$ and $\mathbf{F}$, with bactericidal activity achieved at $3.09 \mathrm{mg} / \mathrm{mL}$ and $2.90 \mathrm{mg} / \mathrm{mL}$, respectively. The extract $\mathbf{A}$ was bactericidal against MSSA and MRSA at high inoculum at the concentration of $4.74 \mathrm{mg} / \mathrm{mL}$, whereas $\mathbf{D}$ had only a slight activity (i.e., $2 \log 10 \mathrm{CFU} / \mathrm{mL}$ reduction compared to the initial inoculum) against high inoculum of MRSA at $1.3 \mathrm{mg} / \mathrm{mL}$, thus showing bacteriostatic effect.

Furthermore, the potent fungicidal activity has been found for both $\mathbf{B}$ and $\mathbf{C}$ extracts, with the absence of growth at the concentration $0.75 \mathrm{mg} / \mathrm{mL}$ and $3.09 \mathrm{mg} / \mathrm{mL}$, respectively. Our assumption was that the mentioned extracts, obtained at room temperature using non-polar extragens ( $n$-hexane and 1,2-dichloroethane) might have resemblance of EO, taking into account that non-polar terpenoids, phenylpropanoids and, in some samples, diterpenoids are constituents of EOs. The extracts A, D and $\mathbf{F}$ lacked to show any effect against $C$. albicans. High resistance of each tested microorganisms has been shown in the case of the extracts $\mathbf{E}, \mathbf{G}$ and $\mathbf{H}$.

There are several reports on the antimicrobial activity of different Sideritis species. For instance, a strong inhibitory effect against Staphylococcus epidermidis was shown by S. trojana EO [57]. According to the authors, a higher content of oxygenated terpenes derivatives in this EO may be responsible for the better antimicrobial activity. Some Spanish Sideritis species showed great antimicrobial efficacy against Gram(+) bacteria and C. albicans fungal strain, with the lack of any activity against Gram $(-)$ bacterial strains [58]. Similar results with a significant activity on Gram(+) bacteria were achieved with EOs of S. curvidens and S. lanata [59]. Six Sideritis taxa of Greek origin have been also analysed 
confirming this rule. S. aureus was found as the most sensitive strain, whereas E. coli, K. pneumoniae and $P$. aeruginosa were resistant to the tested oils [21]. S. lanata EO exhibited the best antimicrobial activity even comparable to the reference antibiotics in the case of S. aureus and M. luteus. Interestingly, one strain of $C$. albicans was more sensitive compared with the other that was resistant to all tested oils. The EOs of two $S$. clandestine subspecies exhibited good antifungal activity [21]. However, some authors reported the same activity on both $\operatorname{Gram}(+)$ and $\operatorname{Gram}(-)$ bacteria, as well as C. albicans, explaining it by the presence of $\alpha$ - and $\beta$-pinene as the main EO constituents [60]. Interestingly, the higher activity against Gram(-) strains has been reported for S. italica, particularly against P. aeruginosa [13].

Aside from EOs, Sideritis solvent extracts were also reported to possess significant antimicrobial activity. Considerable potency was reported for methanolic extracts of Turkish S. ozturkii and S. caesarea [61]. Good activity against S. aureus was shown for hexane extract of S. scardica [62]. Moreover, its EO, the ethanol extract and its different fractions, as well as the $\mathrm{CO}_{2}$-supercritical and conventional extracts have been analyzed on a series of bacterial and yeast strains [19]. Results indicated strong to moderate potency of all investigated extracts, with Gram $(+)$ bacterial strains being more susceptible than the Gram(-) ones, with the exception of Pasteurella multocida and Haemophilus sp. The strongest antibacterial activity was reported against Corynebacterium pseudotuberculosis for the ethyl-acetate and $n$-butanol fractions, as well as for the EO. Interestingly, the mentioned solvent extracts exhibited moderate activity against MRSA with MIC values $0.64 \mathrm{mg} / \mathrm{mL}$, while E. coli and K. pneumoniae proved to be the most resistant. According to the authors, the observed activity might be attributed to the presence of different terpenoids types, including diterpenes that have been reported to display important biological activities [19,63].

However, SP seems to be less investigated. To the best of our knowledge, there is only one report for the antimicrobial activity of its EO. In that study, the strong activity was found against $S$. aureus and Micrococcus luteus with MIC values of $0.006 \mathrm{mg} / \mathrm{mL}$, whereas the good activity was reported against S. epidermidis and C. albicans (the MIC value of $0.024 \mathrm{mg} / \mathrm{mL}$ ). That study also revealed the resistance of Enterococcus faecalis, E. coli, P. aeruginosa and K. pneumoniae strains [21]. As expected, due to similar EO chemical compositions, the results herein presented are mainly in agreement with those previously reported. The observed antimicrobial activities might be very interesting when considering their possible use as a part of the treatment of infections caused by MSSA, MRSA and C. albicans. The predominance of sesquiterpenoids $(64.8 \%)$ could be addressed for the antimicrobial activity, particularly in the case of the opportunistic pathogen S. aureus strains. At least, this could be partly attributed to the $(E)$-caryophyllene content that has already demonstrated good activity against $S$. aureus [64-66]. Other main compounds bicyclogermacrene and germacrene D are known for their antimicrobial activity $[67,68]$, whereas the spathulenol content could also have a synergy to the exhibited activity [69]. However, considering the phytocomplex, EO's trace compounds could also be important as they could act synergistically and/or with antagonistic effects to the antimicrobial actions $[64,70,71]$. 
Table 5. Activity of different Sideritis romana L. subsp. purpurea (Tal. ex Benth.) Heywood extracts against methicillin-susceptible S. aureus, methicillin-resistant $S$. aureus and C. albicans. Low and high inoculum are $5 \times 10^{3}$ and $5 \times 10^{5}$ colony forming units $(\mathrm{CFU}) / \mathrm{mL}$, respectively.

\begin{tabular}{|c|c|c|c|c|c|c|c|}
\hline Sample Name & $\begin{array}{c}\text { MBC } \\
\text { MSSA } \\
\text { (ATCC 29213) Low } \\
\text { Inoculum (mg/mL) }\end{array}$ & $\begin{array}{c}\text { MBC } \\
\text { MSSA } \\
\text { (ATCC 29213) } \\
\text { High Inoculum (mg/mL) }\end{array}$ & $\begin{array}{l}\text { MBC MRSA } \\
\text { Low Inoculum } \\
(\mathrm{mg} / \mathrm{mL})\end{array}$ & $\begin{array}{l}\text { MBC MRSA } \\
\text { High Inoculum } \\
(\mathrm{mg} / \mathrm{mL})\end{array}$ & $\begin{array}{l}\text { MBC C. albicans } \\
\text { (ATCC 14053) Low } \\
\text { Inoculum (mg/mL) }\end{array}$ & $\begin{array}{c}\text { Antibacterial } \\
\text { Activity }\end{array}$ & $\begin{array}{c}\text { Antifungal } \\
\text { Activity }\end{array}$ \\
\hline A & 18.99 & 4.74 & 4.74 & 4.74 & $>18.99$ & Bactericidal & No effect \\
\hline B & $>0.75$ & $>0.75$ & $>0.75$ & $>0.75$ & 0.75 & No effect & Fungicidal \\
\hline $\mathrm{C}$ & 3.09 & 3.09 & 3.09 & 3.09 & 3.09 & Bactericidal & Fungicidal \\
\hline D & $>1.30 *$ & $>1.30$ & $>1.30$ & $>1.30 * *$ & $>1.30$ & Bacteriostatic & No effect \\
\hline $\mathrm{E}^{\#}$ & $>0.89$ & $>0.89$ & $>0.89$ & $>0.89$ & $>0.89$ & No effect & No effect \\
\hline $\mathbf{F}$ & 2.90 & 2.90 & 2.90 & 2.90 & $>5.80$ & Bactericidal & No effect \\
\hline G & $>5.25$ & $>5.25$ & $>5.25$ & $>5.25$ & $>5.25$ & No effect & No effect \\
\hline $\mathbf{H}$ & $>3.07$ & $>3.07$ & $>3.07$ & $>3.07$ & $>3.07$ & No effect & No effect \\
\hline
\end{tabular}

MSSA: methicillin-susceptible S. aureus; MRSA: methicillin-resistant S. aureus; MBC: Minimal Bactericidal Concentration; "\# solubilisation of this extract was not optimal. 


\section{Materials and Methods}

\subsection{Plant Material}

Aerial parts (herba) of wild growing SP were collected in June 2014 in a suburban area Šteke $\left(42^{\circ} 40^{\prime} 94^{\prime \prime} \mathrm{N}, 19^{\circ} 17^{\prime} 41.1^{\prime \prime} \mathrm{E}\right)$ at an altitude of $134 \mathrm{~m}$ and about $5 \mathrm{~km}$ from Podgorica city (Montenegro) during the time of flowering. Air-drying of the collected plant was performed in a shady place for approximately 20 days, packed in paper bags and kept in a dark and cool place. A voucher specimen (No. DB-SP /01) has been deposited at the University of Montenegro, Department of Biology.

Taxonomic identification was performed by M.B. (the author) and was conducted according to the official European flora [22].

\subsection{EO Extraction}

Fifty grams of semi-crushed air-dried plant material and $800 \mathrm{~mL}$ of distilled water were subjected to hydrodistillation for $3 \mathrm{~h}$ using a Clevenger-type apparatus to produce EO. The accumulated oil/water double phase was extracted 3 times with $20 \mathrm{~mL}$ of diethyl ether. The organic layers were dried over anhydrous sodium sulfate $\left(\mathrm{Na}_{2} \mathrm{SO}_{4}\right)$, filtered and deprived of the solvent in vacuo to furnish a yellow pale oil. Prepared SP oil (SPEO) was stored in a tightly closed dark vial until further analysis.

\subsection{Solvent Extraction}

Two independent ways of extraction were applied. Firstly, the finely ground sample of SP herba (15 g) was macerated with methanol $(300 \mathrm{~mL})$ for $48 \mathrm{~h}$. For maceration extraction, the material was placed in an Erlenmeyer flask, the corresponding amount of solvent was added with the sample left to macerate in the dark on a shaker at room temperature. The obtained extract was filtered, and half of the crude methanol extract (A) was partitioned into 4 parts, concentrated in vacuum evaporator, re-dissolved in distilled water, shaken vigorously and additionally extracted with 4 solvents. Using a separating funnel, $35 \mathrm{~mL}$ of each crude extract part (A) was extracted 3 times with $20 \mathrm{~mL}$ of each solvent: $n$-hexane, 1,2-dichloroethane, ethyl-acetate and chloroform, resulting in $\mathbf{B}, \mathbf{C}, \mathbf{D}$ and $\mathbf{E}$ extract fractions, respectively. The extracts were dried under reduced pressure and used to determine the antimicrobial activity.

In addition, shape-dried powdered SP samples were extracted in Soxhlet apparatus for $24 \mathrm{~h}$ according to the standard procedure. Ten grams of each sample was separately extracted with $300 \mathrm{~mL}$ of 3 different solvents. Methanol, acetone and diethyl-ether were used, and obtained extracts were labelled as F, G and $\mathbf{H}$, respectively. After the mixtures were evaporated in vacuum, the final extracts were stored in glass vials in refrigerator until further use.

\subsection{EO Chemical Analysis}

Gas chromatography (GC) analysis was carried out on a HP-5890 Series II GC apparatus (Hewlett-Packard, Waldbronn, Germany), equipped with a split-splitless injector and automatic liquid sampler, attached to a HP-5 column $(25 \mathrm{~m} \times 0.32 \mathrm{~mm}$, film thickness $0.52 \mu \mathrm{m})$ and fitted with an flame ionization detector (FID). Carrier gas flow rate $\left(\mathrm{H}_{2}\right)$ was $1 \mathrm{~mL} / \mathrm{min}$, split ratio 1:30, injector temperature was $250{ }^{\circ} \mathrm{C}$, detector temperature $300{ }^{\circ} \mathrm{C}$, while column temperature was linearly programmed from 40 to $260{ }^{\circ} \mathrm{C}$ (at rate of $4{ }^{\circ} \mathrm{C} / \mathrm{min}$ ), and then kept isothermally at $260{ }^{\circ} \mathrm{C}$ for $10 \mathrm{~min}$. Solutions of samples $(23.9 \mathrm{mg} / \mathrm{mL}$ dichloromethane) were consecutively injected in amount of $1 \mu \mathrm{L}$. Area percentage reports, obtained as result of standard processing of chromatograms, were used as a base for the quantification analysis.

The same analytical conditions as those mentioned for GC-FID were employed for GC-MS analysis, along with a column HP-5MS (30 $\mathrm{m} \times 0.25 \mathrm{~mm}$, film thickness $0.25 \mu \mathrm{m})$, using a HP G 1800C Series II GCD system (Hewlett-Packard, Palo Alto, CA, USA). Helium was used as carrier gas. The transfer line was heated at $260{ }^{\circ} \mathrm{C}$; mass spectra were acquired in electron ionization (EI) mode (70 eV); in the $40-450 \mathrm{~m} / \mathrm{z}$ range. An amount of $0.2 \mu \mathrm{L}$ of sample solution in dichloromethane $(23.9 \mathrm{mg} / \mathrm{mL}) \mathrm{was}$ 
injected. The components of the EOs were identified by comparison of their mass spectra to those from the Wiley 275 and National Institute of Standards and Technology/National Bureau of Standards (NIST/NBS) libraries, using different search engines. Identification of the compounds was achieved by comparing their retention indices and mass spectra with those found in the iterature [72] and supplemented by the Automated Mass Spectral Deconvolution and Identification System software (AMDIS ver. 2.1, Manufacturer, National Institute of Standards and Technology (NIST), Standard Reference Data Program, Gaithersburg, MD, USA), GC-MS Libraries. The experimental values for retention indices were determined by the use of calibrated Automated Mass Spectral Deconvolution and Identification System Software (AMDIS ver. 2.1, National Institute of Standards and Technology (NIST), Standard Reference Data Program, Gaithersburg, MD, USA), GC-MS Libraries, compared to those from available literature [72] and used as an additional tool to confirm the MS findings. The relative proportion of the EO constituents was expressed as percentages obtained by peak area normalization, all relative response factors being taking as one.

\subsection{Determination of Total Phenols Content (TPC)}

TPC was determined by the Folin-Ciocalteu method. In addition, $100 \mu \mathrm{L}$ of methanolic solution of an SP dry extract $(\mathrm{F})(15.63,7.81$ and $3.96 \mu \mathrm{g} / \mathrm{mL}$ final quantity) was mixed with $0.75 \mathrm{ml}$ of Folin-Ciocalteu reagent (previously diluted 10-fold with distilled water) and allowed to stand at $22{ }^{\circ} \mathrm{C}$ for $5 \mathrm{~min} ; 0.75 \mathrm{~mL}$ of sodium bicarbonate $(60 \mathrm{~g} / \mathrm{L})$ solution was added to mixture. After $90 \mathrm{~min}$ at $22{ }^{\circ} \mathrm{C}$, the absorbance was measured at $\lambda_{\max } 725 \mathrm{~nm}$. Gallic acid (0-100 mg/L) was used for calibration of a standard curve. The calibration curve showed the linear regression at $\mathrm{r}>0.99$, and the results were expressed as milligrams of gallic acid equivalents per gram of plant extract dry weight (mg GAE/g DW). Triplicate measurements were taken and data were presented as mean \pm standard deviation (SD) [73].

\subsection{Determination of Total Tannins Content (TTC)}

TTC was calculated using the method described in the European Pharmacopoeia, Ph. Eur. 6.0 [74]. Shortly after, decoctions prepared from the investigated extract F were treated with phosphomolybdotungstic reagent in alkaline medium after and without treatment with hide powder. The absorbance was measured by UV-VIS Spectrophotometer HP 8453 (Agilent Technologies, Santa Clara, CA, USA) at $\lambda_{\max } 760 \mathrm{~nm}$. From the difference in absorbance of total polyphenols and polyphenols not adsorbed by hide powder $\left(A_{1}\right.$ and $A_{2}$, respectively), the content of tannins expressed as pyrogallol $(\%, w / w)$ was calculated from the expression:

$$
T T C=\frac{62.5 \times\left(A_{1}-A_{2}\right) \times m_{2}}{A_{3} \times m_{1}}
$$

where $m_{1}$ represented mass of the sample to be examined (in grams), and $m_{2}$ was mass of pyrogallol (in grams), $A_{3}$ represented the absorbance of pyrogallol standard solution. The results represented the mean $\pm \mathrm{SD}$ of three determinations.

\subsection{Determination of Total Flavonoid Content (TFC)}

TFC expressed as hyperoside was calculated using the method described in the Deutsches Arzneibuch, DAB 10. Briefly, the plant extract $(\mathrm{F})$ was extracted with acetone/ $\mathrm{HCl}$ under reflux condenser; the $\mathrm{AlCl}_{3}$ complex of the flavonoid fraction extracted by ethyl acetate was measured by UV-Vis Spectrophotometer HP 8453 at $\lambda_{\max } 425 \mathrm{~nm}$. The content of flavonoid, expressed as hyperoside percentage, presented the mean \pm standard deviation of three determinations.

\subsection{Bacterial Strains and Growth Media}

For the antimicrobial activity determination, the following microorganisms have been used: methicillin-susceptible Staphylococcus aureus (MSSA (ATCC 29213)) and methicillin-resistant S. aureus 
(MRSA (clinical strain)), Escherichia coli (ATCC 25922), carbapenem-susceptible Klebsiella pneumoniae (clinical strain), carbapenem-resistant K. pneumoniae (clinical strain) and Candida albicans (ATCC 14053).

After bacterial storage on cryovial bead preservation system (Microbank; Pro-Lab Diagnostics, Richmond Hill, Ontario, ON, Canada) at $-80{ }^{\circ} \mathrm{C}$, inoculum was prepared by spreading one cryovial bead on blood agar plate and incubated overnight at $37^{\circ} \mathrm{C}$. One colony was re-suspended in $5 \mathrm{~mL}$ tryptic soy broth (TSB) and incubated at $37^{\circ} \mathrm{C}$ without shaking. Overnight cultures were then adjusted to a turbidity of $0.5 \mathrm{McF}$ arland, corresponding to $\approx 1 \times 10^{8} \mathrm{CFU} / \mathrm{mL}$.

\subsection{Antimicrobials Agents and EO/Extracts Solutions Preparation}

Antimicrobial agents used as reference were provided as purified powder by the manufacturer (Sigma Aldrich, Milan, Italy). Stock solutions at different concentrations were prepared in sterile and pyrogen-free $0.9 \%$ saline or water, according to the manufacturer's instructions.

SPEO and SP extracts were dissolved in 50\% dimethylsulphoxide (DMSO) or water, as appropriate, in order to obtain complete solubilization. Used concentration of DMSO did not interfere with bacterial and fungal viability.

\subsection{Antimicrobial Assay}

Given that the starting solutions were limpid, both minimal inhibitory and bactericidal concentrations (MICs/MBCs) of each reference compound and $\mathrm{EO}$ were determined. In contrast, the starting solution of SP extracts was opalescent; thus, only the MBCs were evaluated.

Two-fold serial dilutions of each antimicrobial agent, SPEO and SP extracts were prepared in $2 \mathrm{~mL}$ Mueller Hinton broth (MHB) in borosilicate glass tubes and incubated for $24 \mathrm{~h}$ at $37^{\circ} \mathrm{C}$. The MIC value was defined as the lowest concentration of antibiotic that completely inhibited visible growth whereas bactericidal activity was defined as $\geq 3-\log 10 \mathrm{CFU} / \mathrm{mL}$ reduction of the initial bacterial count after $24 \mathrm{~h}$ of incubation [75]. Cation-adjusted Mueller Hinton (CAMHB) and Sabouraud broth were used for bacteria and fungi, respectively.

The following antimicrobial agents were used as references: vancomycin (VAN, Sigma Aldrich, purity $>99 \%$ ) and rifampin (RIF, Sigma Aldrich, purity $\geq 97 \%$ ) for Gram-positive microorganisms, meropenem (MEM, Sigma Aldrich, purity $\geq 98 \%$ ) for Gram-negative bacteria, and fluconazole (FLU, Sigma Aldrich, purity $\geq 98 \%$ ) for fungi.

The used bacterial inoculum was $\sim 5 \times 10^{3} \mathrm{CFU} / \mathrm{mL}$. Given the high effect observed against MSSA and MRSA, we tested the EO and SP extracts even at higher inoculum $\left(\sim 5 \times 10^{5} \mathrm{CFU} / \mathrm{mL}\right)$, which represents the likely bacterial amount in case of systemic infections [76].

All the experiments were performed in duplicate.

\section{Conclusions}

Plants have provided the source of inspiration for novel drug compounds. Their extracts and EOs have been shown as useful alternative antimicrobial substances, and numerous studies are continuously published on their uses and applications. In this context, investigations on SP are rather rare. Thus, to initially fulfill this gap in this work, we report for the first time a comprehensive study on EO's chemical composition and its related antimicrobial activity, as well as of different solvent extracts from SP material collected in Montenegro.

SPEO could be described as sesquiterpenoids-rich one $(64.8 \%)$, with only $10.1 \%$ of oxygenated mono- and diterpene fractions. Among the 43 recognized chemical components bicyclogermacrene, germacrene $\mathrm{D},(E)$-caryophyllene and spathulenol were the most abundant. The strongest antimicrobial activities were found against MSSA and especially MRSA strains, as well as against C. albicans strain. These findings were confirmed by several solvent extracts corroborating this plant's usage as a part of the treatment for infectious diseases caused by these opportunistic pathogens. Undoubtedly, further studies are required to evaluate the contribution of SPEO's compounds in the antimicrobial activity expression. The synergism, antagonism and additive effects of the EO's components require additional 
investigation to elucidate the mechanisms underlying their biological activity, for the purpose of accessing new natural antiseptics applicable in the pharmaceutical and food industry. Additionally, studies on SP extracts can be proposed.

Although present in SP, different phenolic compounds, flavonoids and tannins obviously had not shown the same antimicrobial activity as its EO. Generally, derivatives of 2-phenylchromen-4-one (bioflavonoids) and 2-phenyl-3,4-dihydro-2H-chromen-3-ol (tannins), as subgroups within the larger flavonoid group, are considered to be the main groups of active constituents, and, in many national and international pharmacopoeias, these groups of compounds are used for their standardization and quality control. Thus, besides the determination of EO contents, its chemistry profile and antimicrobial potential, we performed the characterization of the plant material in terms of other secondary metabolites.

Bearing in mind the numerous findings on Sideritis species, it can be concluded that SP provides a wide range of application in different fields such as phytochemistry, pharmacology, toxicology or pharmacognosy.

Acknowledgments: The authors are thankful to Branka Knežević for proofreading the paper and Dušan Matković and Predrag Jovanović for the help in field work.

Author Contributions: R.R. and M.B. conceived and initiated the work. M.B. harvested plant material, performed the extraction experiments and drafted the manuscript. V.T. performed the chemical analyses experiments. A.O., A.C., M.D.A. and V.V. performed the microbiology experiments. S.G. contributed with reagents/materials/analysis tools. All of the authors critically edited the manuscript before submission.

Conflicts of Interest: The authors declare no conflict of interest. The founding sponsors had no role in the design of the study; in the collection, analyses, or interpretation of data; in the writing of the manuscript, and in the decision to publish the results.

\section{References}

1. Baratta, M.T.; Dorman, H.J.D.; Deans, S.G.; Figueiredo, A.C.; Barroso, J.G.; Ruberto, G. Antimicrobial and antioxidant properties of some commercial essential oils. Flavour Fragr. J. 1998, 13, 235-244. [CrossRef]

2. Cosentino, S.; Tuberoso, C.I.G.; Pisano, B.; Satta, M.; Mascia, V.; Arzedi, E.; Palmas, F. In Vitro antimicrobial activity and chemical composition of Sardinian Thymus essential oils. Lett. Appl. Microbiol. 1999, 29, 130-135. [CrossRef] [PubMed]

3. Rota, C.; Carramiñana, J.J.; Burillo, J.; Herrera, A. In vitro antimicrobial activity of essential oils from aromatic plants against selected foodborne pathogens. J. Food Prot. 2004, 67, 1252-1256. [CrossRef] [PubMed]

4. Celiktas, O.Y.; Kocabas, E.E.H.; Bedir, E.; Sukan, F.V.; Ozek, T.; Baser, K.H.C. Antimicrobial activities of methanol extracts and essential oils of Rosmarinus officinalis, depending on location and seasonal variations. Food Chem. 2007, 100, 553-559. [CrossRef]

5. Celikel, N.; Kavas, G. Antimicrobial properties of some essential oils against some pathogenic microorganisms. Czech J. Food Sci. 2007, 26, 174-181.

6. Carvalho, I.T.; Estevinho, B.N.; Santos, L. Application of microencapsulated essential oils in cosmetic and personal healthcare products-A review. Int. J. Cosmet. Sci. 2016, 38, 109-119. [CrossRef] [PubMed]

7. Burt, S. Essential oils: Their antibacterial properties and potential applications in foods-A review. Int. J. Food Microbiol. 2004, 94, 223-253. [CrossRef] [PubMed]

8. Tongnuanchan, P.; Benjakul, S. Essential oils: Extraction, bioactivities, and their uses for food preservation. J. Food Sci. 2014, 79, R1231-R1249. [CrossRef] [PubMed]

9. Bakkali, F.; Averbeck, S.; Averbeck, D.; Idaomar, M. Biological effects of essential oils-A review. Food Chem. Toxicol. 2008, 46, 446-475. [CrossRef] [PubMed]

10. De las Heras, B.; Navarro, A.; Díaz-Guerra, M.J.; Bermejo, P.; Castrillo, A.; Boscá, L.; Villar, A. Inhibition of NOS-2 expression in macrophages through the inactivation of NF- $\mathrm{kB}$ by andalusol. Br. J. Pharmacol. 1999, 128, 605-612. [CrossRef] [PubMed]

11. Navarro, A.; De las Heras, B.; Villar, A. Anti-inflammatory and immunomodulating properties of a sterol fraction from Sideritis foetens Clem. Biol. Pharm. Bull. 2001, 24, 470-473. [CrossRef] [PubMed] 
12. Aboutabl, E.A.; Nassar, M.I.; Elsakhawy, F.M.; Maklad, Y.A.; Osman, A.F.; El-Khrisy, E.A.M. Phytochemical and pharmacological studies on Sideritis taurica Stephan ex Wild. J. Ethnopharmacol. 2002, 82, 177-184. [CrossRef]

13. Basile, A.; Senatore, F.; Gargano, R.; Sorbo, S.; Del Pezzo, M.; Lavitola, A.; Ritieni, A.; Bruno, M.; Spatuzzi, D.; Rigano, D.; et al. Antibacterial and antioxidant activities in Sideritis italica (Miller) Greuter et Burdet essential oils. J. Ethnopharmacol. 2006, 107, 240-248. [CrossRef] [PubMed]

14. Küpeli, E.; Şahin, F.P.; Çaliş, I.; Yeşilada, E.; Ezer, N. Phenolic compounds of Sideritis ozturkii and their in vivo anti-inflammatory and antinociceptive activities. J. Ethnopharmacol. 2007, 112, 356-360. [CrossRef] [PubMed]

15. Charami, M.T.; Lazari, D.; Karioti, A.; Skaltsa, H.; Hadjipavlou-Litina, D.; Souleies, C. Antioxidant and antiinflammatory activities of Sideritis perfoliata subsp. perfoliata (Lamiaceae). Phyther. Res. 2008, 22, 450-454. [CrossRef]

16. Ertaş, A.; Öztürk, M.; Boğa, M.; Topçu, G. Antioxidant and anticholinesterase activity evaluation of ent-kaurane diterpenoids from Sideritis arguta. J. Nat. Prod. 2009, 72, 500-502. [CrossRef] [PubMed]

17. Güvenç, A.; Okada, Y.; Akkol, E.K.; Duman, H.; Okuyama, T.; Çaliş, I. Investigations of anti-inflammatory, antinociceptive, antioxidant and aldose reductase inhibitory activities of phenolic compounds from Sideritis brevibracteata. Food Chem. 2010, 118, 686-692. [CrossRef]

18. Demirtas, I.; Ayhan, B.; Sahin, A.; Aksit, H.; Elmastas, M.; Telci, I. Antioxidant activity and chemical composition of Sideritis libanotica Labill. ssp. linearis (Bentham) Borm. (Lamiaceae). Nat. Prod. Res. 2011, 25, 1512-1523. [CrossRef] [PubMed]

19. Tadić, V.; Bojović, D.; Arsić, I.; Dordević, S.; Aksentijević, K.; Stamenić, M.; Janković, S. Chemical and antimicrobial evaluation of supercritical and conventional Sideritis scardica Griseb., Lamiaceae extracts. Molecules 2012, 17, 2683-2703. [CrossRef] [PubMed]

20. Tadić, V.; Jeremić, I.; Dobrić, S.; Isaković, A.; Marković, I.; Trajković, V.; Bojović, B.; Arsić, I. Anti-inflammatory, gastroprotective, and cytotoxic effects of Sideritis scardica extracts. Planta Med. 2012, 78, 415-427. [CrossRef]

21. Koutsaviti, A.; Bazos, I.; Milenković, M.; Pavlović-Drobac, M.; Tzakou, O. Antimicrobial activity and essential oil composition of five Sideritis taxa of Empedoclia and Hesiodia sect. from Greece. Rec. Nat. Prod. 2013, 7, 6-14.

22. Heywood, V. Genus Sideritis L. in Flora Europaea; Tutin, T., Heywood, V., Burges, N., Moore, D., Valentine, S., Walters, S., Webb, D., Eds.; Cambridge University Press: Cambridge, UK, 1973; Volume 2, pp. 138-143.

23. Gonzàlez-Burgos, E.; Carretero, M.E.; Gómez-Serranillos, M.P. Sideritis spp.: Uses, chemical composition and pharmacological activities-A review. J. Ethnopharmacol. 2011, 135, 209-225. [CrossRef] [PubMed]

24. Özcan, M.; Chalchat, J.C.; Akgül, A. Essential oil composition of Turkish mountain tea (Sideritis spp.). Food Chem. 2001, 75, 459-463. [CrossRef]

25. Leporatti, M.L.; Impieri, M. Ethnobotanical notes about some uses of medicinal plants in Alto Tirreno Cosentino area (Calabria, Southern Italy). J. Ethnobiol. Ethnomed. 2007, 3, 34. [CrossRef] [PubMed]

26. Venditti, A.; Frezza, C.; Guarcini, L.; Foddai, S.; Serafini, M.; Bianco, A. Phytochemical study of a species with ethnopharmacological interest: Sideritis romana L. Eur. J. Med. Plants 2016, 12, 1-9. [CrossRef]

27. Gergis, V.; Argyriadou, N.; Poulos, C. Composition of the essential oils of Sideritis cladestina ssp cyllenea and Sideritis sipylea. J. Sci. Food Agric. 1989, 47, 501-507. [CrossRef]

28. Mateo, C.; Sanz, J.; Calderón, J. Essential oil of Sideritis hirsuta. Phytochemistry 1983, 22, 171-173. [CrossRef]

29. Morón, M.; Merle, H.; Primo, J.; Blázquez, M.A.; Boira, H. Diterpene compounds in the essential oil of Sideritis linearifolia Lam. growing in Spain. Flavour Fragr. J. 2005, 20, 205-208. [CrossRef]

30. Kostadinova, E.; Nikolova, D.; Alipieva, K.; Stefova, M.; Stefkov, G.; Evstatieva, L.; Matevski, V.; Bankova, V. Chemical constituents of the essential oils of Sideritis scardica Griseb. and Sideritis raeseri Boiss and Heldr. from Bulgaria and Macedonia. Nat. Prod. Res. 2007, 21, 819-823. [CrossRef] [PubMed]

31. Kirimer, N.; Tabanca, N.; Ozek, T.; Tümen, G.; Baser, K.H. Essential oils of annual Sideritis species growing in Turkey. Pharm. Biol. 2000, 38, 106-111. [CrossRef]

32. Aligiannis, N.; Kalpoutzakis, E.; Chinou, I.B.; Mitakou, S.; Gikas, E.; Tsarbopoulos, A. Composition and antimicrobial activity of the essential oils of five taxa of Sideritis from Greece. J. Agric. Food Chem. 2001, 49, 811-815. [CrossRef] [PubMed]

33. Kirimer, N.; Tabanca, N.; Tümen, G.; Duman, H.; Başer, K.H.C. Composition of the essential oils of four endemic Sideritis species from Turkey. Flavour Fragr. J. 1999, 14, 421-425. [CrossRef] 
34. Ezer, N.; Vila, R.; Cañigueral, S.; Adzet, T. Essential oil composition of four turkish species of Sideritis. Phytochemistry 1996, 41, 203-205. [CrossRef]

35. Palá-Paúl, J.; Pérez-Alonso, M.J.; Velasco-Negueruela, A.; Ballestros, M.T.; Sanz, J. Essential oil composition of Sideritis hirsuta L. from Guadalajara Province, Spain. Flavour Fragr. J. 2006, 21, 410-415. [CrossRef]

36. Rodriguez-Garcia, I.; Munoz-Dorado, M.; Gomez-Mercado, F.; Garcia-Maroto, F. Essential oil composition of Sideritis pusilla (Lange) Pau ssp. J. Essent. Oil Res. 2004, 16, 535-538. [CrossRef]

37. Todorova, M.N.; Christov, R.C.; Evstatieva, L.N. Essential oil composition of three Sideritis species from Bulgaria. J. Essent. Oil Res. 2000, 12, 418-420. [CrossRef]

38. Flamini, G.; Cioni, P.L.; Morelli, I.; Maccioni, S.; Tomei, P. Characterization of the volatile fraction of a Sideritis romana population from Montemarcello (Eastern Liguria). J. Essent. Oil Res. 1994, 6, 239-242. [CrossRef]

39. Pljevljakušić, D.; Šavikin, K.; Janković, T.; Zdunić, G.; Ristić, M.; Godjevac, G.; Konić-Ristić, A. Chemical properties of the cultivated Sideritis raeseri Boiss. \& Heldr. subsp. raeseri. Food Chem. 2011, 124, 226-233. [CrossRef]

40. Baser, K.H.C. Aromatic biodiversity among the flowering plant taxa of Turkey. Pure Appl. Chem. 2002, 74, 527-545. [CrossRef]

41. Ozsoy, N.; Can, A.; Yanardag, R.; Akev, N. Antioxidant activity of Smilax excelsa L. leaf extracts. Food Chem. 2008, 110, 571-583. [CrossRef]

42. Samatha, T.; Shyamsundarachary, R.; Srinivas, P.; Swamy, N.R. Quantification of total phenolic and total flavonoid contents in extracts of Oroxylum indicum L.Kurz. Asian J. Pharm. Clin. Res. 2012, 5, 177-179.

43. Roya, K.; Fatemeh, G. Screening of total phenol and flavonoid content, antioxidant and antibacterial activities of the methanolic extracts of three Silene species from Iran. Int. J. Agric. Crop Sci. 2013, 5, 305-312.

44. Medini, F.; Fellah, H.; Ksouri, R.; Abdelly, C. Total phenolic, flavonoid and tannin contents and antioxidant and antimicrobial activities of organic extracts of shoots of the plant Limonium delicatulum. J. Taibah Univ. Sci. 2014, 8, 216-224. [CrossRef]

45. Dincera, C.; Toruna, M.; Tontula, I.; Topuza, A.; Sahin-Nadeema, H.; Gokturkc, R.S.; Tugrul-Ayd, S.; Ozdemira, F. Phenolic composition and antioxidant activity of Sideritis lycia and Sideritis libanotica subsp. linearis: Effects of cultivation, year and storage. J. Appl. Res. Med. Aromat. Plants 2017, 5, $26-32$.

46. Menković, N.; Gođevac, D.; Šavikin, K.; Zdunić, G.; Milosavljević, S.; Bojadži, A.; Avramoski, O. Bioactive compounds of endemic species Sideritis raeseri subsp. raeseri grown in National Park Galičica. Rec. Nat. Prod. 2013, 7, 161-168.

47. Tunalier, Z.; Kosar, M.; Ozturk, N.; Baser, K.H.C.; Duman, H.; Kirimer, N. Antioxidant properties and phenolic composition of Sideritis species. Chem. Nat. Compd. 2004, 40, 206-210. [CrossRef]

48. Ozkan, G.; Sagdic, O.; Ozcan, M.; Ozcelik, H.; Unver, A. Antioxidant and antibacterial activities of Turkish endemic Sideritis extracts. Grasas Y Aceites 2005, 56, 16-20. [CrossRef]

49. Vaya, J.; Belinky, P.A.; Aviram, M. Antioxidant constituents from licorice roots: Isolation, structure elucidation and antioxidative capacity toward LDL oxidation. Free Radic. Biol. Med. 1997, 23, 302-313. [CrossRef]

50. Sengul, M.; Yildiz, H.; Gungor, N.; Cetin, B.; Eser, Z.; Ercisli, S. Total phenolic content, antioxidant and antimicrobial activities of some medicinal plants. Pak. J. Pharm. Sci. 2009, 22, 102-106. [PubMed]

51. Stešević, D.; Božović, M.; Tadić, V.; Rančić, D.; Stevanović, Z.D. Plant-part anatomy related composition of essential oils and phenolic compounds in Chaerophyllum coloratum, a Balkan endemic species. Flora Morphol. Distrib. Funct. Ecol. Plants 2016, 220,37-51. [CrossRef]

52. Das, N.P.; Pereira, T.A. Effects of flavonoids on thermal autoxidation of palm oil: Structure-activity relationships. JAOCS 1990, 67, 255-258. [CrossRef]

53. Jaakola, L.; Määttä-Riihinen, K.; Kärenlampi, S.; Hohtola, A. Activation of flavonoid biosynthesis by solar radiation in bilberry (Vaccinium myrtillus L.) leaves. Planta 2004, 218, 721-728. [CrossRef] [PubMed]

54. Martin, J.S.; Martin, M.M. Tannin assays in ecological studies: Lack of correlation between phenolics, proanthocyanidins and protein-precipitating constituents in mature foliage of six oak species. Oecologia 1982, 54, 205-211. [CrossRef] [PubMed]

55. Sultana, M.; Verma, P.K.; Raina, R.; Prawez, S.; Dar, M.A. Quantitative analysis of total phenolic, flavonoids and tannin contents in acetone and $n$-hexane extracts of Ageratum conyzoides. Int. J. ChemTech Res. 2012, 4, 996-999.

56. Han, X.; Shen, T.; Lou, H. Dietary polyphenols and their biological significance. Int. J. Mol. Sci. 2007, 8, 950-988. [CrossRef]

57. Kirimer, N.; Baser, K.H. C.; Demirci, B.; Duman, H. Essential oils of Sideritis species of Turkey belonging to the section Empedoclia. Chem. Nat. Compd. 2004, 40, 19-23. [CrossRef] 
58. Villar, A.; Recio, M.C.; Ríos, J.L.; Zafra-Polo, M.C. Antimicrobial activity of essential oils from Sideritis species. Pharmazie 1986, 41, 298-299. [PubMed]

59. Uğur, A.; Varol, Ö.; Ceylan, Ö. Antibacterial activity of Sideritis curvidens and Sideritis lanata from Turkey. Pharm. Biol. 2005, 43, 47-52. [CrossRef]

60. Iscan, G.; Kirimer, N.; Kurkcuoglu, M.; Baser, K.H.C. Composition and antimicrobial activity of the essential oils of two endemic species from Turkey: Sideritis cilicica and Sideritis bilgerana. Chem. Nat. Compd. 2005, 41, 679-682. [CrossRef]

61. Sagdic, O.; Aksoy, A.; Ozkan, G.; Ekici, L.; Albayrak, S. Biological activities of the extracts of two endemic Sideritis species in Turkey. Innov. Food Sci. Emerg. Technol. 2008, 9, 80-84. [CrossRef]

62. Kostadinova, E.; Alipieva, K.; Stefova, M.; Antonova, D.; Evstatieva, L.; Stefkov, G.; Tsvetkova, I.; Naydenski, H.; Bankova, V. Influence of cultivation on the chemical composition and antimicrobial activity of Sideritis spp. Pharmacogn. Mag. 2008, 4, 102-106.

63. Ambrósio, S.R.; Arakawa, N.S.; Esperandim, V.R.; De Albuquerque, S.; Da Costa, F.B. Trypanocidal activity of pimarane diterpenes from Viguiera arenaria (Asteraceae). Phyther. Res. 2008, 22, 1413-1415. [CrossRef] [PubMed]

64. Del Vechio-Vieira, G.; Sousa, O.; Yamamoto, C.; Kaplan, M.C. Chemical composition and antimicrobial activity of the essential oils of Ageratum fastigiatum (Asteraceae). Rec. Nat. Prod. 2009, 3, 52-57.

65. Kasim, L.S.; Olaleye, K.O.; Fagbohun, A.B.; Ibitoye, S.F.; Adejumo, O.E. Chemical composition and antibacterial activity of essential oils from Struchium sparganophora Linn. Ktze Asteraceae. Adv. Biol. Chem. 2014, 4, 246-252. [CrossRef]

66. Gil, E.; Cuca, L.E.; Delgado, W.A. Chemical composition and antimicrobial activity of the essential oil of the leaves of Ocotea caudata (Nees) Mez (Lauraceae) from Colombia. Bol. Latinoam. Caribe Plantas Med. Aromat. 2016, 15, 258-263.

67. Da Silva, L.; Oniki, G.H.; Agripino, D.G.; Moreno, P.R.H.; Young, M.C.M.; Mayworm, M.A.S.; Ladeira, A.M. Biciclogermacreno, resveratrol e atividade antifúngica em extratos de folhas de Cissus verticillata (L.) Nicolson \& Jarvis (Vitaceae). Brazilian J. Pharmacogn. 2007, 17, 361-367. [CrossRef]

68. De Lima, S.G.; Citó, A.M.G.L.; Lopes, J.A.D.; Neto, J.M.M.; Chaves, M.H.; Silveira, E.R. Fixed and volatile constituents of genus croton plants: C. adenocalyx baill—Euphorbiaceae. Rev. Latinoam. Quím. 2010, 38, $133-144$.

69. Vagionas, K.; Graikou, K.; Chinou, I.B.; Runyoro, D.; Ngassapa, O. Chemical analysis and antimicrobial activity of essential oils from the aromatic plants Artemisia afra Jacq. and Leonotis ocymifolia (Burm. F.) Iwarsson var. raineriana (Vision 1) Iwarsson growing in Tanzania. J. Essent. Oil Res. 2007, 19, 396-400. [CrossRef]

70. Pirbalouti, G.A.; Firoznezhad, M.; Craker, L.; Akbarzadeh, M. Essential oil compositions, antibacterial and antioxidant activities of various populations of Artemisia chamaemelifolia at two phenological stages. Braz. J. Pharmacogn. 2013, 23, 861-869. [CrossRef]

71. Silvério, M.S.; Del-Vechio-Vieira, G.; Pinto, M.A.O.; Alves, M.S.; Sousa, O.V. Chemical composition and biological activities of essential oils of Eremanthus erythropappus (DC) McLeisch (Asteraceae). Molecules 2013, 18, 9785-9796. [CrossRef] [PubMed]

72. Adams, R.P. Identification of Essential Oil Components by Gas Chromatography; Allured Publishing Corporation: Carol Stream, IL, USA, 1995; pp. 1-804.

73. Velioglu, Y.S.; Mazza, G.; Gao, L.; Oomah, B.D. Antioxidant activity and total phenolics in selected fruits, vegetables, and grain Products. J. Agric. Food Chem. 1998, 46, 4113-4117. [CrossRef]

74. Blanc, P. European Pharmacopoeia. Br. Med. J. 1964, 2, 192. [CrossRef]

75. Clinical and Laboratory Standars Institute. Performance Standards for Antimicrobial Susceptibility Testing; Fifteenth Informational Supplement M100-S15; CLSI: Wayne, PA, USA, 2005.

76. Venditti, A.; Frezza, C.; Salutari, G.; Di Cecco, M.; Ciaschetti, G.; Oliva, A.; De Angelis, M.; Vullo, V.; Sabatino, M.; Garzoli, S.; et al. Composition of the essential oil of Coristospermum cuneifolium and anti-microbial activity evaluation. Planta Medica Int. Open 2017, in press.

Sample Availability: Samples of the essential oils and extract are not available from the authors.

(C) 2017 by the authors. Licensee MDPI, Basel, Switzerland. This article is an open access article distributed under the terms and conditions of the Creative Commons Attribution (CC BY) license (http://creativecommons.org/licenses/by/4.0/). 